Özdemir, M. H., Tuzcuoğlu, T. / Journal of Yasar University, 2021, 16/62, 945-959

\title{
Clustering of Required Competences of the Employees Working in the Finance-Related Fields of Companies in the Era of Digitalization
}

\section{Dijitalleşme Çağında Firmaların Finansla İlgili Alanlarında Çalışan Çalışanlarının Gerekli Yetkinliklerinin Kümelenmesi}

\author{
Mehmet Hakan ÖZDEMIR, Turkish-German University, Turkey, hakan.ozdemir@tau.edu.tr \\ Orcid No: 0000-0002-7174-9807 \\ Tolga TUZCUOĞLU, Turkish-German University, Turkey, tolga.tuzcuoglu @ tau.edu.tr \\ Orcid No: https://orcid.org/0000-0002-5269-9701
}

\begin{abstract}
This study aims to provide a framework for the clustering of the required competences of the professionals who are working in the finance-related fields of business enterprises. Collecting data from nine commercial departments of the Turkish subsidiary of an international company operating in a knowledge and technology-intense sector, this paper employs cluster analysis to group the required employee competences that are sought in the data-driven business era. The findings suggest that out of the 27 diverse competences analyzed, the average silhouette width is the highest when the competences are divided into 11 different clusters leading to the conclusion that networking, future focus, coping, overview, assuming responsibility, customer-oriented innovation, openness, result focus, establishing focus, managing performance and conceptual thinking are the most required skills that are sought in the finance-related areas of business firms.
\end{abstract}

Keywords: Employee Competence, Digitalization, Cluster Analysis, Silhouette Width

JEL Classification: C38, G30, J24, L22, M12, M51

Öz: Bu çalışma, ticari işletmelerin finans iliş̧kili alanlarında çalışan profesyonellerinin gerekli yetkinliklerinin kümelenmesi için bir çerçeve sağlamayı amaçlamaktadır. Veri odakl işletmeler çağında aranan gerekli çalışan yetkinliklerini gruplandırmak amaciyla, bilgi ve teknoloji yoğun bir sektörde faaliyet gösteren uluslararası bir şirketin Türkiye'deki iştirakinin dokuz ticari departmanından veri elde edilerek kümeleme analizi uygulanmıştır. Bulgular, analiz edilen 27 farkl yetkinliğin 11 farklı kümeye bölündüğünde ortalama silüet genisliğinin en yüksek olduğunu göstermektedir. Buna göre, a ̆̆ kurma, gelecek odakllllk, başa çıma, genel bakış, sorumluluk üstlenme, müşteri odakl yenilikçilik, açıklık, sonuca odaklanma, odak oluşturma, performans yönetme ve kavramsal düşünmenin firmaların finansla ilgili iş alanlarında aranan en gerekli beceriler olduğu sonucu ortaya çımaktadır.

Anahtar Kelimeler: Çalışan Yetkinliği, Dijitalleşme, Kümeleme Analizi, Silüet Genişliği

JEL Sinıflandirmasl: C38, G30, J24, L22, M12, M51

\section{Introduction}

Today, we are living in an environment in which volatility, uncertainty, complexity, and ambiguity are regarded as ordinary challenges for business enterprises. Besides, firms are confronted with digitalization trends to which they have to conform to sustain their long-term existence. Digitization and digitalization are two diverse notions in that digitization pertain to the conversion of analog information into a digital condition such as storing paper-based data into computers; whereas digitalization is a broader concept that encompasses the implementation of digital processes at all the levels of organization (Legner et al., 2017). These levels can be defined as the business models, processes, people, data, and technological Makale Gecmisi / Article History 
infrastructure, in which the people dimension is especially relevant to the mindset and skills of employees (Urbach and Röglinger, 2019). In such an unstable business environment, effective management of financial and non-financial resources plays a pivotal role for companies to remain in the business. On the human resources side, the identification of competence gaps, the deviation between existing and required employee competences, is vital for companies in that company resources are utilized in an optimum way by appointing the right employee in the right place (Bohlouli et al., 2017).

Employee competence refers to the knowledge, experience, and skills of employees which is perceived as a key resource of the organization for competitiveness; in addition, competences allow the employees to execute their tasks such as production, sales, development, etc. most effectively and efficiently possible (Chursin and Tyulin, 2018). In broader sense, employee competence does not only pertain to the technical qualifications which are referred to as hard-skills as well as the interpersonal soft-skills, but they also encompass the skill set that enables the employees to actively contribute to the long term strategic objectives of the companies (Moldovan, 2020). Accordingly, the future-oriented aspect of competence development can be suggested as a fundamental factor for employees for being employable in the market. Apart from that, in such a changing and data-driven environment, employee competence is crucial for the innovative and competitive capacities of business firms (Karnouskos, 2017).

In the light of the points highlighted above, this article investigates the grouping of the most relevant employee competences that are required by the finance-related areas in business firms in today's data-driven business environment. Having this objective in mind, our aim is to conduct a cluster analysis to group numerous competences into more comprehensible subsets based on similarities and dissimilarities. Besides, based on the observed similarities, we will be exploring the possibility of providing a common description for the emerging subsets. The importance of the grouping of employee competences lies in the fact that a compact set of competences may guide the business enterprises to easily set their primary focal points with respect to competence development. In the era of digitalization, competence development is obviously foreseen as a key success and even a survival factor. In accordance with the importance of this issue to companies, the analysis conducted in this study was based on primary data obtained from a multinational company operating in Turkey.

The remainder of the paper is structured as follows. Firstly, the literature on the empirical analysis of employee competences will be briefly summarized. Subsequently, the data used in this study will be presented. This will be then followed by the introduction of the empirical method employed in the analysis. Following the elaboration of the empirical results, the 
conclusion section will summarize the implications for business firms as well as for future research.

\section{Literature Review}

There is plenty of literature on the empirical analysis of employee competence in diverse sectors. Previous studies mainly included the collection of survey data based on subjective assessment in which competence related variables were often verified through expert opinions and interviews. In addition, factor analysis was the most frequent empirical method used in data analysis. To illustrate, Cowan et al. (2008) studied the measurement of nursing competences in five European countries through a survey with 588 participants. Data collection was based on the self-assessment of selected 108 competence parameters in the form of questions where the participants made their subjective degree of competence assessment on a scale of four frequency parameters corresponding to each question. The authors conducted factor analysis as well as analyzed the Cronbach's coefficient alpha values and concluded eight main competence dimensions and compared them in the given four different countries. Alias et al. (2015) studied the measurement of employee leadership skills by collecting survey data from 1040 participants. The authors put forward a measurement model utilizing confirmatory factor analysis and concluded that the communication of leadership features and the act of being a role model for the subordinates were the most desired leadership skills sought by employers. Ko (2015) measured employee competence for research and development personnel in the foodservice sector through confirmatory factor analysis. The author collected data through a questionnaire where the research and development competence was represented by the parameters derived from the literature as well as through expert interviews. Gathering data from 85 respondents, the author finalized the competence scale with five main dimensions, which were activeness and endurance, product knowledge and capability, innovation and change, responsibility, and cost calculation. Lee and Seomun (2016) focused on the measurement of the compassion competence of nurses by conducting an exploratory factor analysis. The authors firstly reviewed the literature to design their survey and validated the survey questions through expert interviews in the sector. Having a sample of 660 observations, the factor analysis concluded the compassion competence with three main constructs, which were communication, sensitivity, and insight, respectively.

On the other hand, Bohlouli et al. (2017) proposed a mathematical model for competence assessment. The authors developed a tree for the required employee competences and assessed the competence level of selected participants based on the proposed competence model. As for the evaluation of the existing employee competence, the authors incorporated 
the data from 360-degree feedback forms that included the assessment from others' points of view as well as through surveys in which employees expressed their own competence perception of themselves. On the other hand, the required competences were gathered through the pre-determined competence requirement of the organization for the underlying position. Focusing on 11 individuals, the authors used the Scott-Knott clustering algorithm and classified the participants into under, over, and best-qualified groups. As for another example, Lin and Chang (2018) analyzed the required skills of logistics employees from the perspective of logistics practitioners and academics by collecting survey data from 181 respondents. The authors validated the survey contents with evidence from previous research and interviews with sector experts and divided the skill sets into two groups, which were business and logistics skills, respectively. The outcome of the factor analysis revealed that data analysis, customer and strategic management, international trade and regulation, computer, finance, and communication skills were the fundamental business-related employee skills; in addition, transport, global supply chain, and information management were the main logistics skills sought in the sector. Cheng and Chen (2019) formed a competence scale for medical clinical undergraduates based on four selected medical education standards including the findings from the literature as well as expert interviews. Analyzing data from a sample of 228 participants, the authors applied factor and correlation analyses. The study revealed that the medical competence index had eight main dimensions, which were medical knowledge, public health, or social science, essential clinical skills, advanced clinical skills, communication skills, advanced study skills, critical thinking and adaptation, and professionalism, respectively.

A closer look into the empirical methods that were employed in the prior studies of employee competences reveals several common points. Firstly, the empirical analyses employed in the studies were mainly based on primary data collected through surveys. In most cases, the employee competences in question were refined or validated by domain experts. Secondly, factor analysis was observed as the most frequent method to reduce a large number of competences into smaller entities and these entities were renamed based on their communalities.

\section{Data and Method}

\subsection{Data}

The employee competence data set used in this study was collected from nine commercial departments of the Turkish subsidiary of an international company operating in a knowledge and technology-intense sector. As one of the largest multinational companies in Turkey in terms of sales volume and the number of employees, the company has diverse production 
facilities as well as a wide network of sales points across Turkey. The employee competence data set used in this study was consisted of 27 diverse skills that are summarized in Table 1 below. (In the dendrograms showing the cluster analysis results later, numbers in parentheses will be used instead of skill names.) The definition of the data set was finalized through a three-step approach. Firstly, various types of competences that were addressed in the previous employee competence measurement studies were compiled in a broad list. Subsequently, this list was refined by the human resources department of the Turkish subsidiary of the international company based on the group's generally accepted competence model. As for the last step, the refined list of employee competences was revised in bilateral meetings with the aforementioned nine commercial department managers of the company. The managers who attended the meetings were responsible for the finance, financial accounting, management accounting, internal audit, tax, foreign trade, logistics, purchasing, business excellence, and IT departments of the entity. The meetings, which took place in July 2019, were designed as a qualitative analysis that was based on asking questions in the form of an interview. As a result of the interviews, the final competence list was concluded.

Subsequently, nine department managers responsible for the mainly finance-related activities of the company were asked to evaluate the relative importance of each competence in the final list that is the most required in the current digital transformation era on a ten-point scale. In this evaluation, "1" represented the point awarded to a competence that was the most unrelated to digitalization. In contrast, "10" denoted the point awarded to a competence that was the most related to digitalization.

Table 1. List of the competences used in the study

\begin{tabular}{|l|l|l|}
\hline Analytical Thinking (17) & Establishing Focus (22) & Leading Others (24) \\
\hline Autonomy (18) & Flexibility \& Agility (11) & Managing Change (2) \\
\hline $\begin{array}{l}\text { Building Collaborative and } \\
\text { Cooperative Relationships (14) }\end{array}$ & Forward Thinking (4) & $\begin{array}{l}\text { Managing Performance } \\
(7)\end{array}$ \\
\hline Communication (8) & Fostering Innovation (20) & Results Orientation (3) \\
\hline Conceptual Thinking (12) & Fostering Teamwork (1) & Self Confidence (26) \\
\hline Customer Orientation (6) & Influencing Others (16) & Strategic Perspective (9) \\
\hline Data Analytics (15) & Initiative (23) & $\begin{array}{l}\text { Stress Management } \\
\text { Resilience (27) }\end{array}$ \\
\hline $\begin{array}{l}\text { Diagnostic Information } \\
\text { Gathering (25) }\end{array}$ & $\begin{array}{l}\text { Interpersonal Awareness and } \\
\text { Empathy (5) }\end{array}$ & Technical Expertise (10) \\
\hline $\begin{array}{l}\text { Entrepreneurial Orientation } \\
\text { (19) }\end{array}$ & Judgment (13) & Thoroughness (21) \\
\hline
\end{tabular}

\subsection{Cluster Analysis}

This paper employs cluster analysis to group the required employee competences that are sought in the data-driven business era. Cluster analysis is a statistical method aimed at decreasing the volume of a large dataset into smaller groups by detecting similar and 
dissimilar characteristics; in other words, classifying and grouping data based on similarities (Wierzchoń and Kłopotek, 2018:9).

In this paper, we will only deal with dissimilarity measures, but first, let $\mathbf{X}$ be a $n \times p$ multivariate data matrix containing the variable values describing each object to be clustered:

$$
\mathbf{X}=\left[\begin{array}{cccc}
x_{11} & x_{12} & \cdots & x_{1 p} \\
x_{21} & \cdots & \cdots & \cdots \\
\vdots & \vdots & \vdots & \vdots \\
x_{n 1} & \cdots & \cdots & x_{n p}
\end{array}\right]
$$

where $x_{i j}$ gives the value of the $j$ th variable on object $i$ (Everitt et al., 2011:5). With $x_{i j}$ being quantitative, proximities between objects are quantified by distances measures $d_{i j}$ fulfilling the following conditions:

1) $\quad d_{i j}=d_{j i}$

2) $\quad d_{i j} \geq 0$ and $d_{i i}=0$

3) $\quad d_{i j}+d_{i m} \geq d_{j m}$

A distance measure commonly used is the Minkowski distance

$$
d_{i j}=\left[\sum_{k=1}^{p}\left|x_{i k}-x_{j k}\right|^{r}\right]^{1 / r} \text { with } r \geq 1 \text {. }
$$

The Euclidean distance $(r=2)$ and the city block distance $(r=1)$ are special cases of the Minkowski distance (Everitt et al., 2011:49-50).

Sometimes, variables can be clustered instead of objects. This type of clustering can be found in the questionnaire design. The first draft of a questionnaire can often contain more questions than is necessary. Responses to some questions in a questionnaire tested on a small number of participants may be highly correlated. Cluster analysis can be applied to identify the questions that are similar to each other. In this case, the distance matrix based on one minus the Pearson correlation coefficient is used as the distance matrix. After similar questions are collected in the same cluster, only one of them can be chosen as a representative for the whole cluster (Tryfos, 1998:16-17).

Clustering methods are generally divided into hierarchical clustering and non-hierarchical clustering methods (Alpar, 2013:322).

\subsubsection{Hierarchical Clustering Methods}

Hierarchical clustering methods are also subdivided into agglomerative hierarchical methods and divisive hierarchical methods (Doğan and Başokçu, 2010:66). In agglomerative hierarchical methods, each object is initially considered as a singleton cluster, and then the two closest clusters are combined into a new cluster. At each step, the number of clusters is reduced and finally, all objects are contained in one cluster (Alpar, 2013:322). Below is a 
brief summary of the differences between the main agglomerative hierarchical clustering methods:

a) Single linkage method: In the single linkage method, the distance between clusters is defined as the minimum distance between the pair of objects, one in one cluster, one in the other (Everitt et al., 2011:79).

b) Complete linkage method: In this method, the distance between clusters is defined as the maximum distance between the pair of objects, one in one cluster, one in the other (Everitt et al., 2011:79).

c) Average linkage method: The distance between two clusters is defined as the average distance between all pairs of objects, one in one cluster, one in the other (Everitt et al., 2011:79).

d) Centroid linkage method: The distance between two clusters is defined as the distance between their centroids (gravity centers) (Wierzchoń and Kłopotek, 2018:30).

e) Ward linkage method: This method was introduced by Ward (1963). It follows a series of clustering steps that start with clusters that contain one object, it ends with one cluster that contains all objects. At each step, this method makes whichever merger of two clusters that will result in the smallest increase in the value of the sumof-squares index, or variance (Romesburg, 1984:129-130).

Each of the methods described above has advantages and disadvantages. Sometimes chaining may occur among clusters in the single linkage method. Chaining means that several clusters may be joined simply because one of their objects is within close proximity of an object from a separate cluster as the minimum distance is considered in single linkage method (Yim and Ramdeen, 2015:11). That leads to long and loose clusters (Kassambara, 2017:71). There is no chaining problem in the complete linkage method. However, outlying objects may prevent the close cluster from merging. In the complete linkage method, more compact clusters can be created (Kassambara, 2017:71). The merge point may change at each step of clustering; therefore, the concept of a persistent best merge does not apply in the complete linkage method; whereas it applies in the single linkage method (Cimiano, 2006:71-73). Average linkage can be considered as a compromise between the single linkage and complete linkage (Yim and Ramdeen, 2015:11). In the average linkage, the concept of persistent best merge does not apply either (Velldal, 2012:11). In the centroid linkage, inversions can occur. That means that the combination similarity can increase during the clustering (Velldal, 2012:9). The Ward linkage method tends to find clusters with an equal number of objects and may impose a spherical structure where none exists (Everitt et al., 2011:84). 
Contrary to agglomerative methods, there is a large cluster at the beginning of divisive clustering methods. In the next steps, the most distant objects are separated from each other and smaller clusters are formed. This process continues until each object clusters on its own (Alpar, 2013:322).

\subsubsection{Non-Hierarchical Clustering Methods}

In non-hierarchical clustering methods, the number of clusters is specified a priori by the researcher (Yim and Ramdeen, 2015:9). The advantages of non-hierarchical clustering methods over hierarchical methods are that they can be applied to larger data sets and are less sensitive to outliers. The non-hierarchical clustering method most used is the k-means method. In this method, the minimum number of clusters is determined as two and the maximum number of clusters is equal to or less than the number of objects. The goal is to divide the objects into clusters whose number is determined by the researcher, with the highest intra-class similarity and the lowest inter-class similarity (Alpar, 2013:342).

\section{Empirical Results}

Each of the hierarchical methods described above has advantages and disadvantages, as mentioned above. Bratchell (1989) emphasized that there is no such solution as the best solution, and the researcher should try different methods and compare the results. However, there are several methods for clustering validation. One of them is the silhouette analysis that measures how well an object is clustered and estimates the distance between clusters (Kassambara, 2017:140). In other words, since the most appropriate clustering method is not yet known prior to the analysis, the calculation of the average silhouette widths may illuminate the way throughout the selection of the most appropriate clustering method as well as the number of clusters. The silhouette width $s_{i}$ is calculated by

$$
S_{i}=\frac{b_{i}-a_{i}}{\max \left(a_{i}, b_{i}\right)}
$$

where $\boldsymbol{a}_{\boldsymbol{i}}$ is the average distance between the $\boldsymbol{i}^{\text {th }}$ object and all other objects of the cluster to which the $\boldsymbol{i}^{\text {th }}$ object belongs and $\boldsymbol{b}_{\boldsymbol{i}}$ is the smallest of the average distances of the $\boldsymbol{i}^{\text {th }}$ object to all objects in any other cluster to which the $\boldsymbol{i}^{\text {th }}$ object does not belong. If the value of $\boldsymbol{s}_{\boldsymbol{i}}$ is equal to 1 , the object is well clustered. If it is equal to -1 , the object is poorly clustered (Wierzchoń and Kłopotek, 2018:166).

In this research, nine department managers evaluated 27 competences, as mentioned in Section 3.1. Accordingly, these 27 competences will be clustered. Therefore, the distance matrix based on one minus the Pearson correlation coefficient is used, as explained at the end of Section 3.2. 
Table 2 shows the average silhouette width at the different number of clusters obtained by hierarchical agglomerative clustering with different linkage methods. The average silhouette width was calculated using the $\mathrm{R}$ command eclust.

As it can be seen very clearly from Table 2, the Ward linkage and average linkage yielded the best results with 11 clusters and the same highest average silhouette width of 0.3598661 .

Figures 1 and 2 show the dendrograms with 11 clusters using average linkage and Ward linkage. The competences 7, 12, and 22 (managing performance, conceptual thinking, and establishing focus) form a cluster by themselves. Competences 2 and 8 (managing change, communication), 3 and 13 (results orientation and judgment), 6 and 20 (customer orientation and fostering innovation), 11 and 18 (flexibility \& agility and autonomy) form three different clusters. Competences 5, 15 and 25 (interpersonal awareness and empathy, data analytics and diagnostic information gathering) and 16, 21 and 27 (influencing others, thoroughness, stress management/resilience) form two different clusters. Competences 1, 10, 14, 17 and 23 (fostering teamwork, technical expertise, building collaborative and cooperative relationships, analytical thinking and initiative) and 4, 9, 19, 24 and 26 (forward-thinking, strategic perspective, entrepreneurial orientation, leading others and self-confidence) form two different clusters.

Figures 3 and 4, which are the same, show the silhouette plots using the average linkage and Ward linkage, respectively. 
Table 2. Average silhouette width at different number of clusters with respect to selected linkage methods

\begin{tabular}{|c|c|c|c|c|c|}
\hline $\begin{array}{l}\text { Number } \\
\text { of clusters }\end{array}$ & $\begin{array}{c}\text { Average } \\
\text { silhouette } \\
\text { width } \\
\text { (Single } \\
\text { Linkage) }\end{array}$ & $\begin{array}{c}\text { Average } \\
\text { silhouette } \\
\text { width } \\
\text { (Complete } \\
\text { Linkage) } \\
\end{array}$ & $\begin{array}{c}\text { Average } \\
\text { silhouette } \\
\text { width } \\
\text { (Average } \\
\text { Linkage) }\end{array}$ & $\begin{array}{c}\text { Average } \\
\text { silhouette } \\
\text { width } \\
\text { (Centroid } \\
\text { Linkage) }\end{array}$ & $\begin{array}{c}\text { Average } \\
\text { silhouette } \\
\text { width } \\
\text { (Ward } \\
\text { Linkage) }\end{array}$ \\
\hline 2 & 0.1768741 & 0.3047334 & 0.307972 & 0.1768741 & 0.2887891 \\
\hline 3 & -0.08745972 & 0.2372576 & 0.2548939 & 0.1111026 & 0.2799521 \\
\hline 4 & -0.1375985 & 0.2421599 & 0.2924811 & 0.03002376 & 0.2987961 \\
\hline 5 & -0.131071 & 0.2299991 & 0.2790397 & -0.02475019 & 0.3016747 \\
\hline 6 & -0.1998537 & 0.2372096 & 0.279859 & 0.1795039 & 0.3044777 \\
\hline 7 & -0.1236389 & 0.2971672 & 0.3272728 & 0.1204687 & 0.3260986 \\
\hline 8 & -0.1409976 & 0.3215987 & 0.3087826 & 0.1933815 & 0.327635 \\
\hline 9 & -0.0172224 & 0.3236844 & 0.3143827 & 0.1673591 & 0.3357105 \\
\hline 10 & -0.03633921 & 0.3161975 & 0.3413991 & 0.1564965 & 0.3526023 \\
\hline 11 & 0.09706482 & 0.353128 & 0.3598661 & 0.1202868 & 0.3598661 \\
\hline 12 & 0.09646891 & 0.3414586 & 0.3255141 & 0.107077 & 0.3414586 \\
\hline 13 & 0.06767334 & 0.315531 & 0.3042888 & 0.2391904 & 0.315531 \\
\hline 14 & 0.2021778 & 0.3125594 & 0.2943057 & 0.2304325 & 0.3125594 \\
\hline 15 & 0.1675644 & 0.2918455 & 0.2735918 & 0.2004552 & 0.2918455 \\
\hline 16 & 0.09272465 & 0.2708797 & 0.251064 & 0.1769105 & 0.2708797 \\
\hline 17 & 0.152864 & 0.2486965 & 0.2254427 & 0.2202981 & 0.2486965 \\
\hline 18 & 0.1712951 & 0.2096781 & 0.1946767 & 0.1966797 & 0.2179306 \\
\hline 19 & 0.1289512 & 0.1789122 & 0.1744008 & 0.1744008 & 0.2015484 \\
\hline 20 & 0.1009775 & 0.1695393 & 0.158136 & 0.1445547 & 0.183274 \\
\hline 21 & 0.07943532 & 0.1512649 & 0.130574 & 0.1282899 & 0.1512649 \\
\hline 22 & 0.1086698 & 0.1214189 & 0.1007279 & 0.1086698 & 0.1214189 \\
\hline 23 & 0.08674942 & 0.1100258 & 0.08705018 & 0.08705018 & 0.1100258 \\
\hline 24 & 0.03451382 & 0.09727847 & 0.09727847 & 0.09727847 & 0.09727847 \\
\hline 25 & 0.02421676 & 0.07535813 & 0.07535813 & 0.07535813 & 0.07535813 \\
\hline 26 & 0.02312253 & 0.02312253 & 0.02312253 & 0.02312253 & 0.02312253 \\
\hline
\end{tabular}




\section{Cluster Dendrogram}

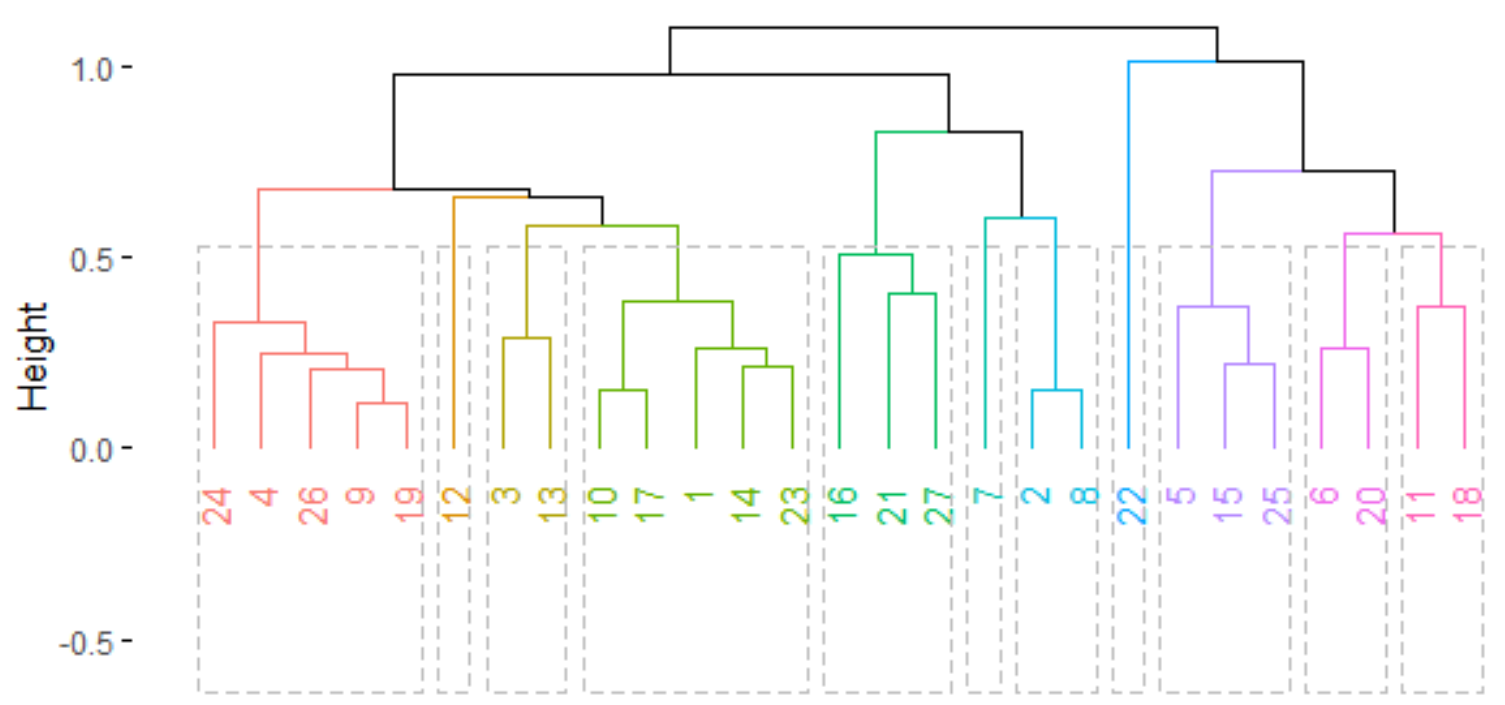

Figure 1. Dendrogram with 11 clusters using average linkage

\section{Cluster Dendrogram}

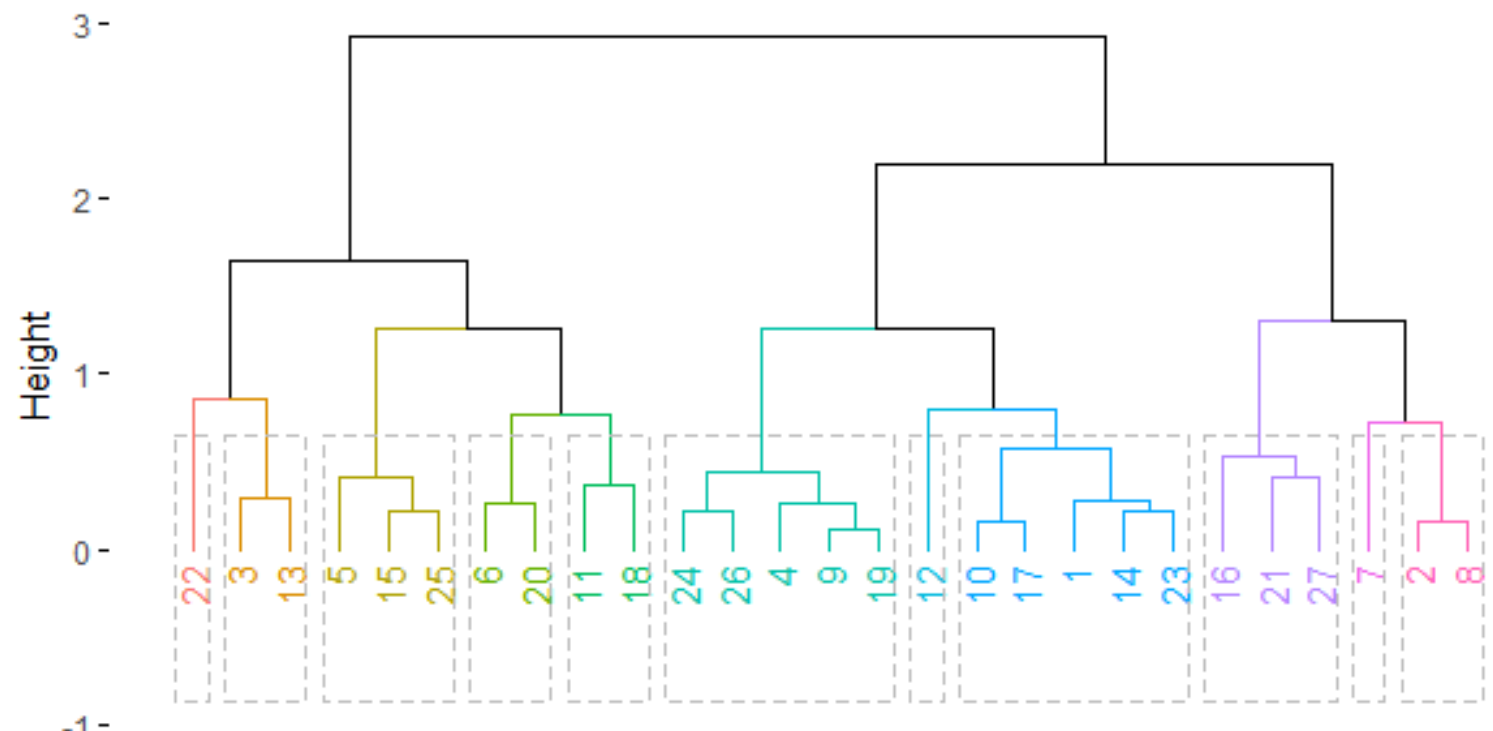

Figure 2. Dendrogram with 11 clusters using Ward linkage 


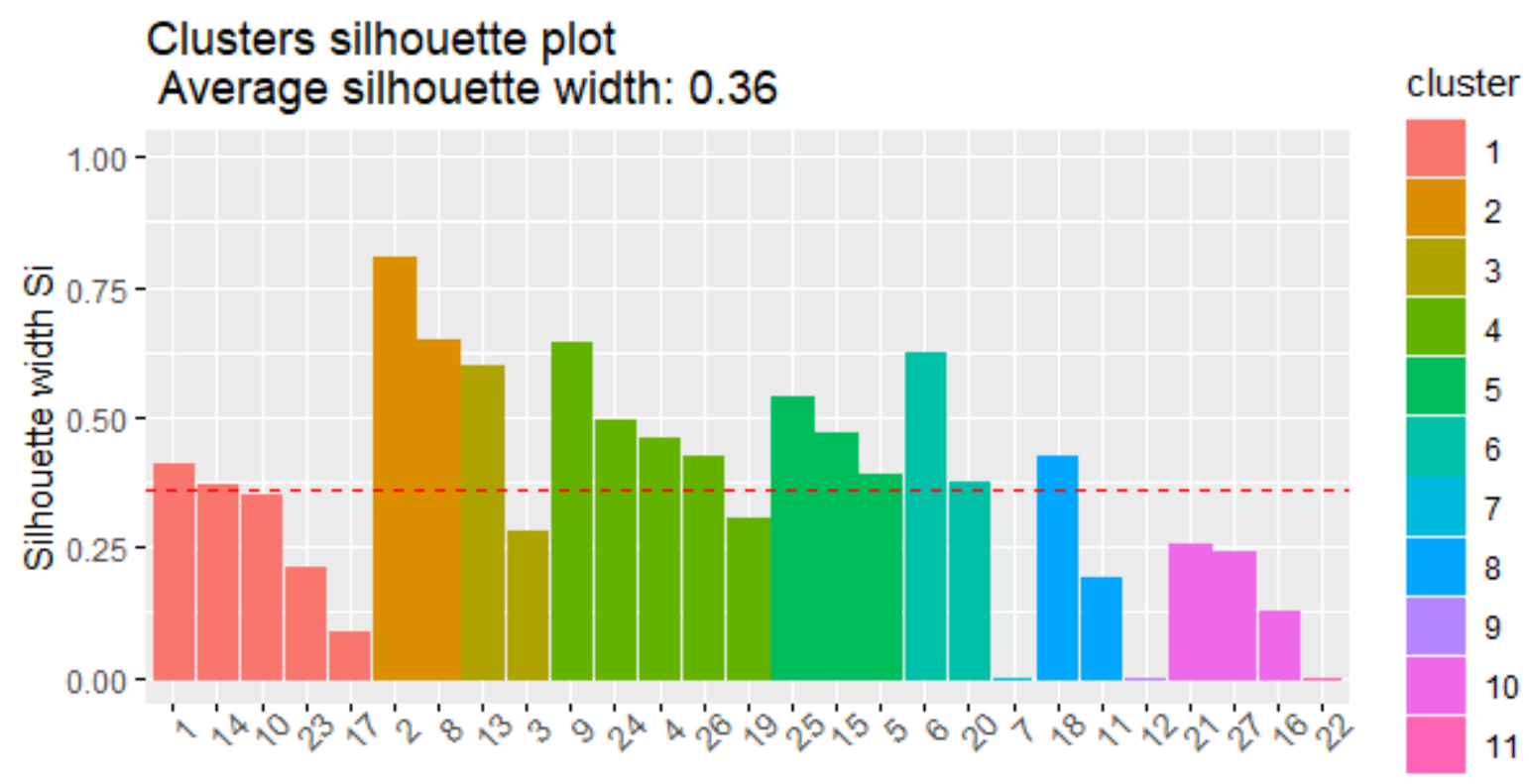

Figure 3. Silhouette plot using average linkage

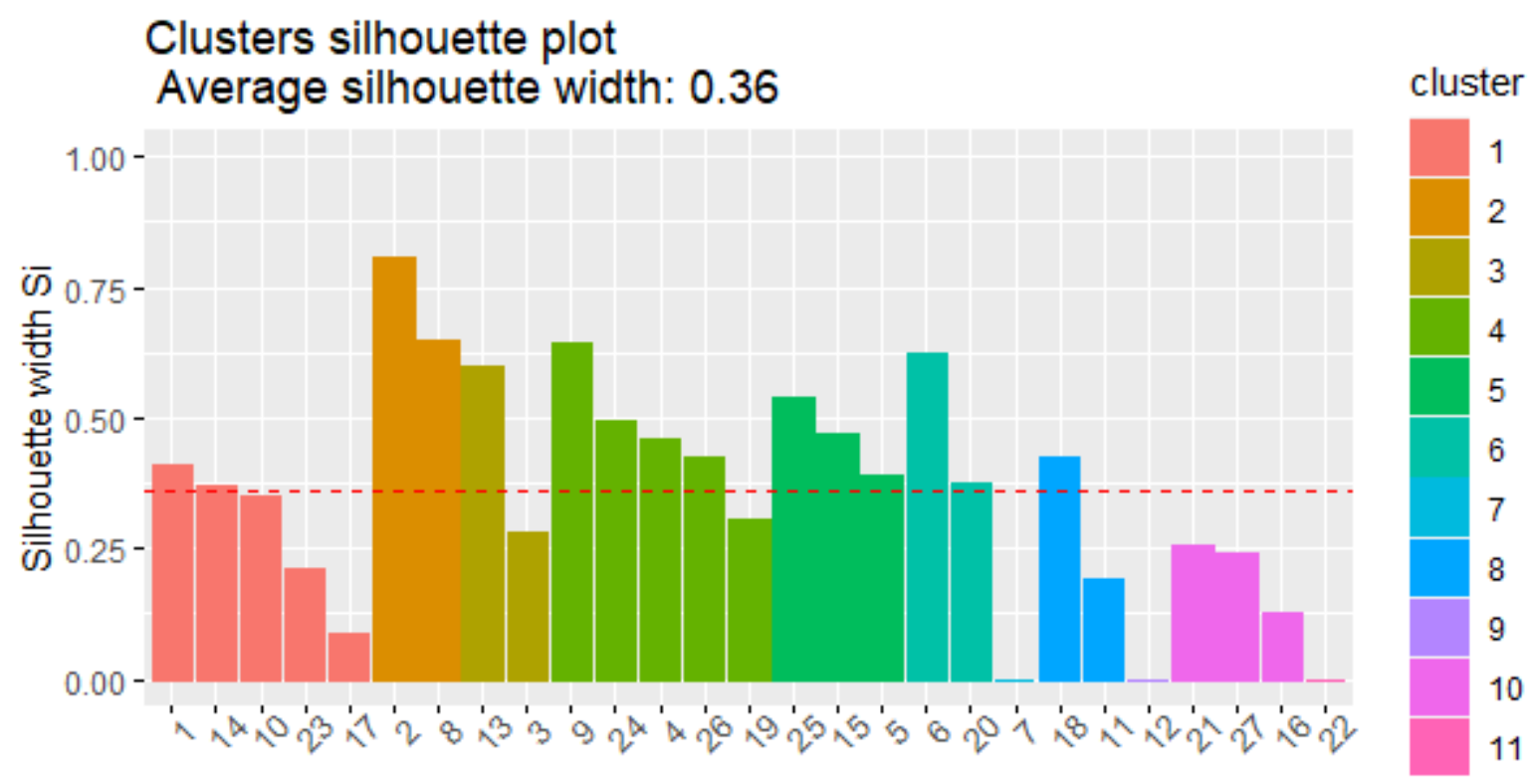

Figure 4. Silhouette plot using Ward linkage

\section{Conclusion}

In this study, cluster analysis was performed to group the required employee competences that are sought in the data-driven business era in the finance-related areas of companies. Only hierarchical clustering methods were used, and the average silhouette width was calculated in $\mathrm{R}$ to find the optimal number of clusters. Both the Ward linkage and average linkage yielded the best result with 11 clusters and the same highest average silhouette width.

In this respect, 27 employee competences were clustered into 11 groups in which conceptual thinking, managing performance and establishing focus were the competences 
clustered separately under their own description. As for clusters comprising of two competences, results suggested four distinct clusters, which were results orientation and judgement; managing change and communication; customer orientation and fostering innovation; and flexibility \& agility and autonomy. The clusters formed with these two competence groups were described as result focus, openness, customer oriented innovation and assuming responsibility, respectively. In addition, the study concluded two clusters with three competences each. In this sense, interpersonal awareness and empathy, data analytics and diagnostic information gathering were grouped as the overview competence; additionally, the competences influencing others, thoroughness and stress management / resilience were grouped as coping. The rest of the two clusters were comprised of five competences, respectively. Accordingly, forward-thinking, strategic perspective, entrepreneurial orientation, leading others and self-confidence were clustered into the group future focus. Similarly, fostering teamwork, technical expertise, building collaborative and cooperative relationships, analytical thinking and initiative were named under the cluster networking.

Similar to the previous studies on the empirical analysis of employee competences, we validated the set of competences that were used in the study with domain experts through bilateral interviews and employed primary data in the empirical analysis. On the other hand, whereas previous studies mainly utilized factor analysis to reduce the number of competences into smaller sub-groups, our approach was based on clustering analysis to group similar competences with each other and describe them according to the findings of analysis. 1The clusters formed as a result of the empirical analysis were as expected. In a data-driven and knowledge-based business environment which is also characterized by elevated volatility, uncertainty, complexity, and ambiguity as well, it is incumbent on the financial management of the firms to manage costs effectively through efficiency gains in the indirect areas which can be achieved through competent professionals that have a broad overview with a futureoriented strategic focus, perceive change as a chance, are willing to assume additional responsibility, prioritize the customer needs and are able to build internal and external networks to foster collaboration and expertise. There are some limitations to the study. First, the study focused only on soft skills where technical skills are not addressed. In addition, the empirical analysis included data from a single company representing a sector or a few sectors. Apart from the inclusion of technical competences additionally, future research may integrate a larger dataset across companies operating in different sectors, which may allow for sector comparisons as for competence requirements. 
Özdemir, M. H., Tuzcuoğlu, T. / Journal of Yasar University, 2021, 16/62, 945-959

\section{Acknowledgments}

This manuscript benefited from the valuable comments of two anonymous reviewers. 


\section{REFERENCES}

Alias, Rosima, Mohd Hanapiah Ismail, and Nurhanis Sahiddan. 2015. "A Measurement Model for Leadership Skills Using Confirmatory Factor Analysis (CFA).” Contemporary Issues in Management and Social Science Research. 172 (January): 717-24.

Alpar, Reha. 2013. Uygulamalı Çok Değişkenli İstatiksel Yöntemler, Detay Yayıncılık.

Bohlouli, Mahdi, Nikolaos Mittas, George Kakarontzas, Theodosios Theodosiou, Lefteris Angelis, and Madjid Fathi. 2017. "Competence Assessment as an Expert System for Human Resource Management: A Mathematical Approach." Expert Systems with Applications 70 (March): 83-102.

Bratchell, Nicholas. 1989. Cluster analysis. Chemometrics and Intelligent Laboratory Systems 6(2):105-25.

Cheng, and Chen. 2019. "An Exploration of Medical Education in Central and Southern China: Measuring the Professional Competence of Clinical Undergraduates." International Journal of Environmental Research and Public Health 16 (October): 4119.

Chursin, Alexander, and Andrey Tyulin. 2018. Competence Management and Competitive Product Development. Springer International Publishing AG.

Cimiano, Philipp. 2006. Ontology Learning and Population from Text: Algorithms, Evaluation and Applications, Springer.

Cowan, David T., Dame Jenifer Wilson-Barnett, Ian J. Norman, and Trevor Murrells. 2008. "Measuring Nursing Competence: Development of a Self-Assessment Tool for General Nurses across Europe.” International Journal of Nursing Studies 45(6): 902-13.

Doğan, Nuri, and T. Oğuz Başokçu. 2010. "İstatistik Tutum Ölçeği için uygulanan faktör analizi ve aşamalı kümeleme analizi sonuçlarının karşılaştırılması.” Ĕgitim ve Psikolojide Ölçme ve Değerlendirme Dergisi 1(2):65-71.

Everitt, Brian S., Sabine Landau, Morven Leese, and Daniel Stahl. 2011. Cluster analysis 5th Edition, Wiley.

Karnouskos, Stamatis. 2017. "Massive Open Online Courses (MOOCs) as an Enabler for Competent Employees and Innovation in Industry." Computers in Industry 91 (October): 1-10.

Kassambara, Alboukadel. 2017. Practical guide to cluster analysis in R: Unsupervised machine learning (Edition 1). Sthda.

Ko, Wen-Hwa. 2015. "Constructing a Professional Competence Scale for Foodservice Research \& Development Employees from an Industry Viewpoint." International Journal of Hospitality Management 49 (August): 66-72.

Lee, Youngjin, and GyeongAe Seomun. 2016. "Development and Validation of an Instrument to Measure Nurses’ Compassion Competence.” Applied Nursing Research 30 (May): 76-82.

Legner, Christine, Torsten Eymann, Thomas Hess, Christian Matt, Tilo Böhmann, Paul Drews, Alexander Maedche, Nils Urbach, and Frederik Ahlemann. 2017. "Digitalization: Opportunity and Challenge for the Business and Information Systems Engineering Community." Business \& Information Systems Engineering 59 (July): 301-8.

Lin, Chi-Chang, and Chia-Hsun Chang. 2018. "Evaluating Skill Requirement for Logistics Operation Practitioners: Based on the Perceptions of Logistics Service Providers and Academics in Taiwan." The Asian Journal of Shipping and Logistics 34(4): 328-36.

Moldovan, Liviu. 2020. "A Tool for Continuous Evaluation of Competences and Approaches to Employment Support." 13th International Conference Interdisciplinarity in Engineering, INTER-ENG 2019, 3-4 October 2019, Targu Mures, Romania 46 (January): 263-70.

Romesburg, H. Charles. 1984. Cluster Analysis for Researchers. Lifetime Learning Publications.

Tryfos, Peter. 1998. "Chapter 15: Cluster Analysis" in Methods for Business Analysis and Forecasting: Text \& Cases, Wiley. Accessed September 23, 2020, http://www.yorku.ca/ptryfos/methods.htm

Velldal, Erik. 2012. "INF4820, Algorithms for AI and NLP: Hierarchical Clustering." Accessed September 8, 2020. https://www.uio.no/studier/emner/matnat/ifi/nedlagteemner/INF4820/h12/undervisningsmateriale/06_clustering.pdf

Urbach, Nils, and Maximilian Röglinger, eds. 2019. Digitalization Cases, Management for Professionals. Springer International Publishing AG.

Ward Jr, Joe H. 1963. "Hierarchical grouping to optimize an objective function." Journal of the American Statistical Association 58(301):236-44.

Wierzchoń, Sławomir T., and Mieczysław A. Kłopotek. 2018. Modern Algorithms of Cluster Analysis. Springer International Publishing AG.

Yim, Odilia, and Kylee T. Ramdeen. 2015. "Hierarchical cluster analysis: comparison of three linkage measures and application to psychological data." The quantitative methods for psychology 11(1):8-21. 